\title{
Label-free quantitative proteomics of CD133-positive liver cancer stem cells
}

\author{
Sheng-Ta Tsai ${ }^{1,2}$, Chih-Chiang Tsou ${ }^{3}$, Wan-Yu Mao², Wei-Chao Chang ${ }^{2}$, Hsin-Ying Han², Wen-Lian Hsu ${ }^{3}$, \\ Chung-Leung Li ${ }^{2,4}$, Chia-Ning Shen ${ }^{1,2^{*}}$ and Chung-Hsuan Chen ${ }^{1,2,5,6^{*}}$
}

\begin{abstract}
Background: CD133-positive liver cancer stem cells, which are characterized by their resistance to conventional chemotherapy and their tumor initiation ability at limited dilutions, have been recognized as a critical target in liver cancer therapeutics. In the current work, we developed a label-free quantitative method to investigate the proteome of CD133-positive liver cancer stem cells for the purpose of identifying unique biomarkers that can be utilized for targeting liver cancer stem cells. Label-free quantitation was performed in combination with ID-based Elution time Alignment by Linear regression Quantitation (IDEAL-Q) and MaxQuant.

Results: Initially, IDEAL-Q analysis revealed that 151 proteins were differentially expressed in the CD133-positive hepatoma cells when compared with CD133-negative cells. We then analyzed these 151 differentially expressed proteins by MaxQuant software and identified 10 significantly up-regulated proteins. The results were further validated by RT-PCR, western blot, flow cytometry or immunofluorescent staining which revealed that prominin-1, annexin $A 1$, annexin $A 3$, transgelin, creatine kinase $B$, vimentin, and EpCAM were indeed highly expressed in the CD133-positive hepatoma cells.
\end{abstract}

Conclusions: These findings confirmed that mass spectrometry-based label-free quantitative proteomics can be used to gain insights into liver cancer stem cells.

Keywords: Hepatocellular carcinoma, LC-MS/MS, Liver cancer stem cells, Label-free quantitation

\section{Background}

Numerous studies have identified a subpopulation of cells in a wide variety of tumors that possess stem cell characteristics, including the ability to self-renew and differentiate into heterogeneous tumor cells [1,2]. These cells are called "cancer stem cells" (CSCs) or "tumor-initiating cells" (TICs) [3]. CSCs were first discovered in leukemia $[4,5]$ and were subsequently identified in various solid tumors, including melanoma [6], breast cancer [7], brain tumors [8,9], prostate cancer [10], head and neck cancer [11], lung cancer [12], colon cancer [13,14], pancreatic adenocarcinoma [15], ovarian cancer [16], and hepatocellular carcinoma (HCC) $[17,18]$. There is accumulating evidence that CSCs display drug resistance to many conventional therapies

\footnotetext{
* Correspondence: cnshen@gate.sinica.edu.tw; winschen@gate.sinica.edu.tw ${ }^{1}$ Institute of Biochemistry \& Molecular Biology, National Yang-Ming University, Taipei, Taiwan

${ }^{2}$ Genomics Research Center, Academia Sinica, Taipei, Taiwan

Full list of author information is available at the end of the article
}

which therefore leads to cancer recurrence, suggesting that new cancer therapeutics may be required to target and eliminate the cancer stem cells. Therefore, a better understanding of the mechanisms that control the aspects of self-renewal and survival in cancer stem cells is very important. Furthermore, the identification of unique biomarkers could also facilitate the development of therapeutics that target CSCs.

The CD133 antigen (prominin-1) is a cell-surface glycoprotein that contains 865 amino acids, 5 transmembrane domains, and 2 glycosylated extracellular loops [19]. The glycosylated CD133 antigen that is recognized by AC133 monoclonal antibodies is a cell surface marker of hematopoietic stem cells and possibly hepatic stem cells [20,21]. Recent findings have also revealed that the glycosylated CD133 antigen is also a potential marker for the isolation of CSCs from a wide variety of tumor tissues, including glioblastomas, lung cancer, pancreatic adenocarcinomas, prostate cancer, colon cancer and hepatocellular carcinomas $[8,10,12$ -

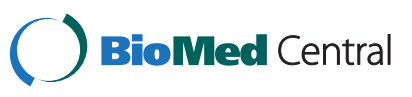


14,22-24]. Recent reports suggest a subpopulation of liver cancer cells expressed the glycosylated CD133 antigen are with characteristics of CSCs and can lead to cancer progression and relapse [17,23-25]. More importantly, CD133 is a prognostic marker that has either been linked to poor survival for liver cancer patients [26] or has been correlated with higher grade tumors [27]. Therefore, CD133-positive liver cancer cells have been recognized as a critical target for liver cancer therapies.

The mass spectrometry (MS)-based proteomics technology has been shown as a powerful tool for largescale protein identification and quantitation. To investigate the differentially expressed proteins in a complex biological system, strategies for reproducible and accurate quantification are required. Several quantitative proteomics methods have been developed, including stable isotope labeling and label-free methods [28]. Although isotope labeling techniques have been widely used in quantitative proteomics research, researchers are increasingly turning to label-free shotgun proteomics techniques. Although both methods have certain strengths and weaknesses, MS-based label-free quantitative proteomics may be adequate for application in complex biological systems $[29,30]$. Over the past few years, a limited number of groups have applied proteomics to investigate CSCs. For example, Ma et al., and Lee et al. had utilized two-dimension electrophoresis (2-DE) to determine the differently expressed proteins in $\mathrm{CD}_{133^{+}}$liver cancer cells and identified ALDH1A1 and transgelin were highly expressed in $\mathrm{CD}_{133^{+}}$cells compared with CD133- cells [31,32]. Nevertheless, the 2-DE method is less efficient and time-consuming. Recently, Van Houdt et al. applied LC-MS/MS in combination with spectral counting for label-free quantitation to analyze colorectal cancer stem cells and identified BIRC6 as a key mediator of drug resistance against cisplatin and oxaliplatin [33]. However, label-free quantitative proteomics encounters the problem of less accuracy although the method is rather simpler and cheaper.

In order to improve accuracy of label-free quantitative proteomics, in the current work, label-free quantitation was performed in combination with ID-based Elution time Alignment by Linear regression Quantitation (IDEAL-Q) [34] and MaxQuant [35,36]. Subpopulations of Huh7 hepatoma cells that did or did not express the glycosylated CD133 antigen (prominin-1) were sorted and analyzed by mass spectrometry-based comparative proteomics. The protein abundance in $\mathrm{CD}_{133^{+/-}}$Huh7 hepatoma cells and normal human hepatocytes was initially determined by averaging the peptide abundances with IDEAL-Q which computed the area of the extracted ion chromatogram (XIC) followed with validation by MaxQuant. The experimental design is shown in Figure 1. Using the approach, we

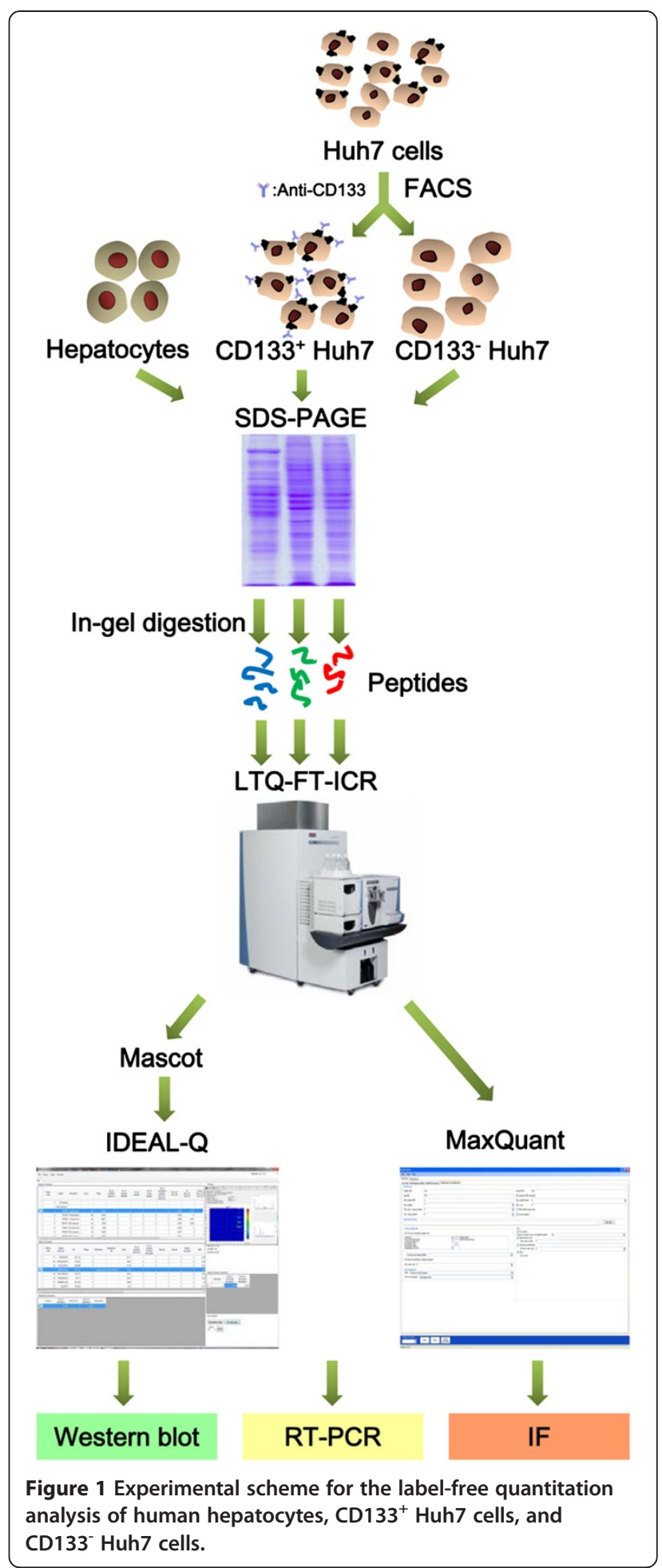

established the proteomes of $\mathrm{CD} 133^{+/-}$Huh7 hepatoma cells and normal human hepatocytes and identified a number of proteins that differentially expressed in the CD133-positive hepatoma cells. The results showed that the MS-based label-free quantitative proteomics 
method developed in the current work can be used to gain further insights into liver CSCs.

\section{Results}

Characterization of the CD133-positive subpopulation of the Huh7 hepatoma cells

Previous works have demonstrated that Huh7 hepatoma cells contain a CD133-positive subpopulation, which displays the characteristics of cancer stem cells $[17,23,25]$. We initially determined whether the Huh7 cells contained a subpopulation of CSCs that expressed the CD133 antigen. The Huh7 cell lines were first stained with fluorescence-conjugated primary antibodies against the surface marker CD133 and then analyzed using flow cytometry. We categorized the $20 \%$ of cells displaying the strongest fluorescence as $\mathrm{CD} 133^{+}$ Huh7 cells and the $20 \%$ of cells displaying the weakest fluorescence as $\mathrm{CD}_{133^{-}}$Huh7 cells. A re-analysis was performed, which showed that $\mathrm{CD}_{133^{+}}$cells and CD133 cells were indeed two different populations of cells (Figure 2A). Further characterization of the CD $133^{+}$Huh7 cells by RT-PCR and immunofluorescent staining showed that these cells expressed higher levels of prominin-1, $\beta$-catenin, and cytokeratin 19 (CK19) (Figure 2B-C), which confirmed previous findings [17]. In order to determine whether $\mathrm{CD} 133^{+} \mathrm{Huh} 7$ cells expressed characteristics of CSCs, we performed sphere-forming experiments, TopFlash assay and drug resistance test. Indeed, sphere forming assay has been widely used to examine anchorage-independent growth ability of stem cells and CSCs in liver [37-39]. As shown in Figure 2D-E, in comparing with CD133Huh7 cells, CD133 ${ }^{+}$Huh7 cells generated more spheres. Moreover, Wnt/ $\beta$-catenin pathway is known to play a key role in the self-renewal of normal and tumorigenic liver stem/progenitor cells [40,41], we then examined if $\mathrm{CD}_{133^{+}}$cells have activated $\mathrm{Wnt} / \beta-$ catenin pathways. Immunofluorescent staining was performed and showed that some $\mathrm{CD}_{133^{+}}$cells had nuclear $\beta$-catenin (Figure 2F). TopFlash reporter assay was carried out and further confirmed that $\mathrm{CD} 133^{+}$ subpopulations had higher Wnt/ $\beta$-catenin pathway activities compared with CD133 subpopulation or unsorted Huh7 cells (Figure 2G). Since CSCs are known to display drug resistance to many conventional therapies, we then examined the drug resistance of Huh7 cells against two conventional drugs, 5-fluoroucacil (5-FU) and Sorafenib which are widely used in treating HCC. The sensitivity of Huh7 cells was determined using MTT colorimetric assay followed by FACS analysis. As shown in Figure 2H, Huh7 cells displayed resistance to 5-FU or Sorafenib with higher IC50 value of 160 and $3 \mu \mathrm{M}$ respectively. Most importantly, the majority of survived cells from 5-FU or Sorafenib treatment were $\mathrm{CD}_{133^{+}}$(Figure 2I) suggesting CD133 ${ }^{+}$ Huh7 cells display higher drug resistance.

\section{Determination of the proteomes of the $\mathrm{CD} 133^{+}$and CD133- subpopulations of Huh7 cells and normal hepatocytes}

To identify the differentially expressed proteins in $\mathrm{CD}_{133^{+}}$liver cancer stem cells, we determined the proteomes of human hepatocytes and the $\mathrm{CD}_{133^{+}}$and CD133 subpopulations of the Huh7 cells. All protein extracts, isolated from either the hepatocytes or the $\mathrm{CD}_{133^{+}}$and $\mathrm{CD}_{133^{-}}$subpopulations, were analyzed twice using LC LTQ-FT-ICR. We identified 13,643, 17,707 , and 21,865 non-redundant peptides from extracts of the human hepatocytes, $\mathrm{CD}_{133^{+}}$, and CD133- Huh7 subpopulations, respectively. Additionally, 1,869, 2,936, and 3,009 proteins were identified from extracts of the human hepatocytes, $\mathrm{CD} 133^{+}$, and $\mathrm{CD} 133^{-}$subpopulations, respectively. Among the proteins identified, 1,471, 2,260, and 2,567 proteins, respectively, had more than 2 peptides that were detected. A comparison of the proteins identified in the three cell types is shown in Figure 3A. The detailed information on the complete proteomes of the human hepatocytes, CD133 ${ }^{+}$Huh7 cells, and CD133Huh7 cells are included in Additional file 1: Table S1, Additional file 2: Table S2 and Additional file 3: Table S3.

Identification of the significantly up-regulated and downregulated proteins in the $\mathrm{CD} 133^{+}$subpopulations of the Huh7 cells

To identify proteins that were either significantly upregulated or down-regulated in the $\mathrm{CD}_{13}{ }^{+}$subpopulation, IDEAL-Q was used to calculate the ratios of the protein abundance and to determine the significant difference $(p<0.01)$ in the ratios of the protein abundance between the $\mathrm{CD}_{133^{+}}$and $\mathrm{CD} 133^{-}$subpopulations. The distribution of the ratios of the protein abundance between the $\mathrm{CD}_{133^{+}}$and $\mathrm{CD} 133^{-}$subpopulations is shown in Figure 3B. The data showed no significant difference in the level of most of the proteins, and a total 151 proteins were found to be differentially expressed in the $\mathrm{CD}_{133^{+}}$subpopulations when compared with the CD133- subpopulations. In order to select the specific target proteins in the $\mathrm{CD} 133^{+}$subpopulations, the differentially expressed proteins were also compared with those in normal human hepatocytes and further analyzed by MaxQuant [35]. Based on the IDEAL-Q and MaxQuant analysis, we found 10 proteins that were abundantly expressed in the $\mathrm{CD}_{133^{+}}$cell populations when compared to the CD133- cell populations and the normal human hepatocytes (Table 1). These proteins have been quantified by using more than three unique peptides. The difference in the expression level of these 10 proteins in $\mathrm{CD}_{133^{+}}$, CD133- Huh7 cell populations, and 


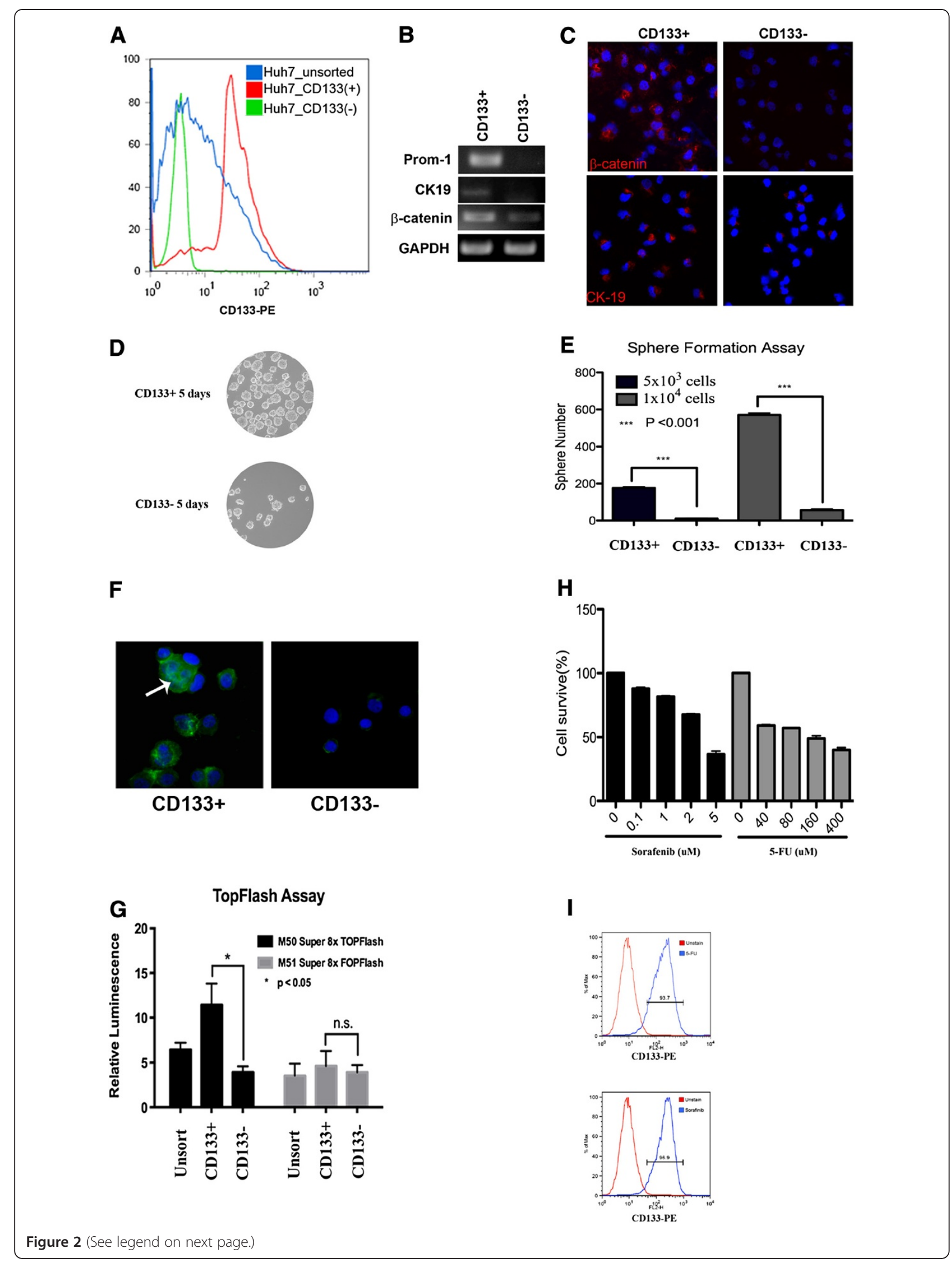


(See figure on previous page.)

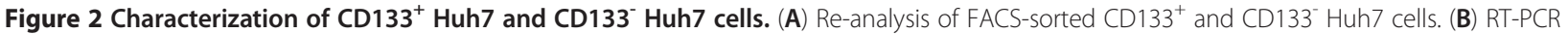

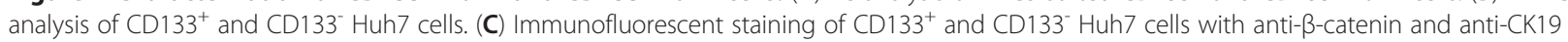
antibodies. (D) Formation the anchorage-independent spheres in stem cell medium. (E) Quantitative analysis of sphere-forming efficiency of CD133 ${ }^{+}$and CD133- Huh7 cells. (F) Immunofluorescent staining of CD133 ${ }^{+}$and CD133- Huh7 cells with anti- $\beta$-catenin antibody. Arrowed cells showed nuclear staining of $\beta$-catenin. (G) Huh7 cells were transfected with equal amounts of either Super8xTOPFlash reporter or

Super8xFOPFlash reporter constructs. After 48 hours, the TopFlash/FopFlash luciferase activity of CD133 ${ }^{+}$and CD133- Huh7 cells was measured. Values shown are relative luminescence. (H) Huh7 cells were treated with different concentration of 5-fluoroucacil (5-FU) or Sorafenib for 48 hours. The cell survival was determined using MTT assay. (I) Huh7 cells were treated with $160 \mu \mathrm{M}$ of 5-FU or $3 \mu \mathrm{M}$ of Sorafenib for 48 hours. The expression of CD133 in survived cells was analyzed by flow cytometry

the normal human hepatocytes was statistically significant. Since, the subpopulations of the Huh7 cells were sorted based on the expression of prominin-1 (CD133), and the analytic data showed the amount of prominin-1 protein in the $\mathrm{CD} 133^{+}$Huh7 cells was approximately 15fold higher than that in the CD133- Huh7 cells and 76fold higher than that in the human hepatocytes; hence, these results suggest that the quantitative analysis using IDEAL-Q is reliable. As expected, several markers of liver cancer stem cells or hepatic stem cells could also been identified by IDEAL-Q and shown to be upregulated in the $\mathrm{CD}_{133^{+}}$subpopulations. For example, transgelin, an actin-binding protein, has been proven to be highly expressed in $\mathrm{CD} 133^{+}$Huh7 cells [31]. In our study, the expression level of transgelin was 16-fold higher in the $\mathrm{CD} 133^{+}$subpopulations than that in the CD133- populations. Among the proteins that were significantly up-regulated in the $\mathrm{CD} 133^{+}$subpopulations of the Huh7 cells, we verified that the $\mathrm{CD} 133^{+}$Huh7 cells expressed higher levels of annexin A1, annexin A3, prominin-1, transgelin, creatine kinase $\mathrm{B}$, vimentin, and EpCAM (Figure 4A-D), using RT-PCR, western blot, immunocytochemical analysis, and FACS analysis. The level of epithelial cell adhesion molecule (EpCAM), which has also been shown to be highly expressed in liver cancer stem cells [42], was 2.6-fold higher in the CD133 ${ }^{+}$ subpopulations compared with the $\mathrm{CD} 133^{-}$subpopulations. The expression level of EpCAM in $\mathrm{CD} 133^{+}$and CD133- populations were also detected by flow cytometry (Figure 4D). Two other hepatic stem cell markers, vimentin and cytokeratin 19, were 8-fold and 3.7-fold higher, respectively, in the $\mathrm{CD}_{133^{+}}$subpopulations when compared to the $\mathrm{CD} 133^{-}$subpopulations. Since it has been shown that Snaill-induced epithelial-tomesenchymal transition is accompanied by enhancement in stem cell characteristics during liver carcinogenesis [43], we also examined the level of mesenchymal markers by western blot (Figure 4B). Although the level of Ecadherin was not decreased in $\mathrm{CD} 133^{+}$Huh7 cells, however, in addition to vimentin, up-regulation of $\mathrm{N}$-cadherin was also observed. Taken together, these results suggest that mass spectrometry-based label-free quantitative proteomics developed in the current study can be used to gain the insights into liver cancer stem cells.

In addition to the significantly up-regulated proteins, we also found 60 proteins that were down-regulated in the $\mathrm{CD}_{133^{+}}$subpopulations when compared to the CD133 subpopulations. The detailed list of the up- and down-regulated proteins is listed in Additional file 4: Table S4. Furthermore, in order to investigate the protein locations of the identified proteins, the Gene Ontology cellular component (GOCC) terms were annotated for
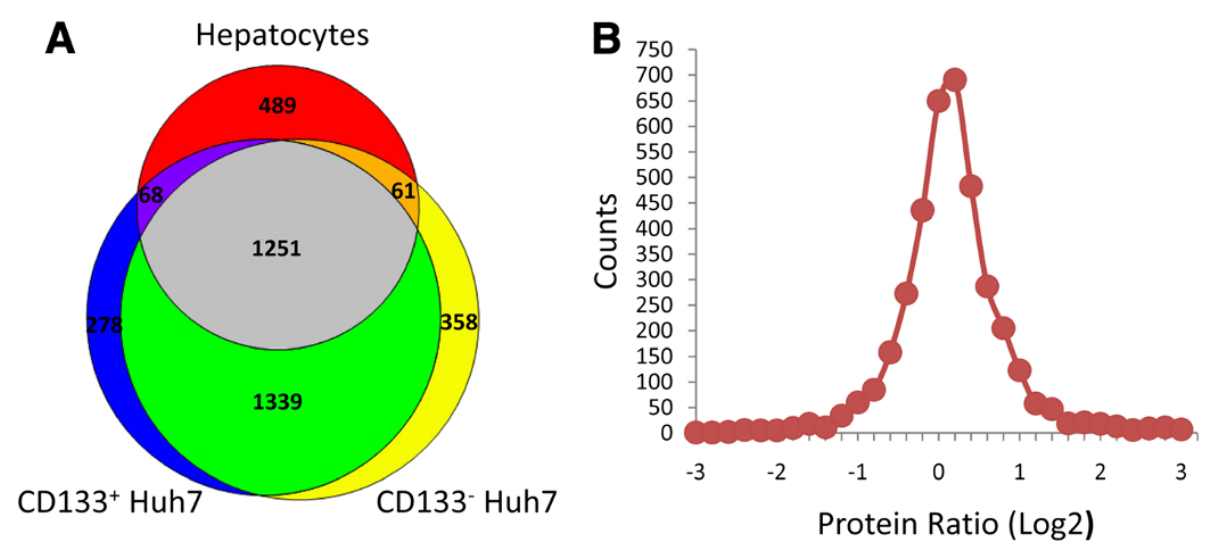

Figure 3 Proteome analysis. (A) Comparison of the protein profiles of human hepatocytes, CD133 ${ }^{+}$Huh7 cells, and CD133 Huh7 cells. The number of identified proteins in human hepatocytes (red), CD133+ Huh7 cells (blue), and CD133 Huh7 cells (yellow) are shown by a Venn diagram. The other colors represent the overlap regions. (B) The protein ratio distribution of CD133+ Huh7 cells/CD133- Huh7 cells 
Table 1 Significantly up-regulated proteins in the CD133+ Huh7 cells

\begin{tabular}{|c|c|c|c|c|c|c|c|c|c|c|c|}
\hline Accession & Protein description & Score & $\begin{array}{l}\text { Unique } \\
\text { peptides }\end{array}$ & $\begin{array}{l}\text { Hepatocyte } \\
\text { area }\end{array}$ & $\begin{array}{l}\text { CD133- } \\
\text { Huh7 area }\end{array}$ & $\begin{array}{l}\text { CD133 }^{+} \\
\text {Huh7 area }\end{array}$ & 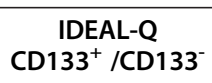 & $\begin{array}{c}\text { IDEAL-Q } \\
\text { CD133 }{ }^{+} / \text {Hepatocyte }\end{array}$ & P-value ${ }^{a}$ & 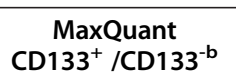 & $\begin{array}{c}\text { Plasma } \\
\text { membrane }\end{array}$ \\
\hline IPI00216138 & Transgelin & 552 & 10 & $0.21 \pm 0.05$ & $0.13 \pm 0.06$ & $2.11 \pm 0.30$ & 15.96 & 9.99 & $<0.001$ & 33.94 & \\
\hline IPI00012540 & Prominin-1 (CD133) & 170 & 4 & $0.01 \pm 0.01$ & $0.05 \pm 0.01$ & $0.69 \pm 0.09$ & 15.24 & 76.22 & $<0.001$ & 124.06 & $\mathrm{O}$ \\
\hline IPI00418471 & Vimentin & 1726 & 30 & $0.38 \pm 0.03$ & $0.82 \pm 0.06$ & $6.77 \pm 0.47$ & 8.24 & 17.77 & $<0.001$ & 21.51 & $\mathrm{O}$ \\
\hline IPI00218918 & Annexin A1 & 303 & 5 & $0.02 \pm 0.002$ & $0.04 \pm 0.01$ & $0.33 \pm 0.03$ & 7.83 & 21.93 & $<0.001$ & 101.44 & $\mathrm{O}$ \\
\hline IPI00186460 & Collagen alpha-1 (II) chain & 227 & 4 & $0.01 \pm 0.01$ & $0.15 \pm 0.05$ & $0.94 \pm 0.06$ & 6.10 & 67.07 & $<0.001$ & 11.95 & \\
\hline IPI00024095 & Annexin A3 & 919 & 15 & $0.15 \pm 0.003$ & $0.44 \pm 0.07$ & $2.69 \pm 0.48$ & 6.10 & 17.70 & $<0.001$ & 17.13 & $\mathrm{O}$ \\
\hline IPI00329650 & Nucleoporin NUP53 & 252 & 4 & $0.05 \pm 0.02$ & $0.28 \pm 0.04$ & $1.29 \pm 0.13$ & 4.71 & 26.41 & $<0.001$ & 3.62 & $\mathrm{O}$ \\
\hline IPI00296215 & $\begin{array}{l}\text { Tumor-associated calcium signal } \\
\text { transducer } 1 \text { (EpCAM) }\end{array}$ & 204 & 3 & $0.01 \pm 0.004$ & $0.12 \pm 0.01$ & $0.31 \pm 0.02$ & 2.56 & 27.73 & 0.010 & 6.17 & $\mathrm{O}$ \\
\hline IPI00386208 & $\begin{array}{l}\text { Gastric-associated } \\
\text { differentially-expressed } \\
\text { protein YA61P }\end{array}$ & 224 & 4 & $0.01 \pm 0.01$ & $0.42 \pm 0.04$ & $0.97 \pm 0.07$ & 2.34 & 108.22 & 0.008 & 13.90 & \\
\hline IPI00022977 & Creatine kinase B-type & 1181 & 19 & $0.86 \pm 0.15$ & $6.39 \pm 0.58$ & $13.50 \pm 2.43$ & 2.11 & 15.66 & 0.009 & 2.03 & \\
\hline
\end{tabular}

a Significance B based on log(2) transformed ratios and intensity between CD133 ${ }^{+}$Huh7 cells and CD133- Huh7 cells.

${ }^{b}$ The ratio was calculated by MaxQuant label-free quantification.

c Proteins possibly locate on plasma membrane from Gene Ontology Cellular Component (GOCC) database. 


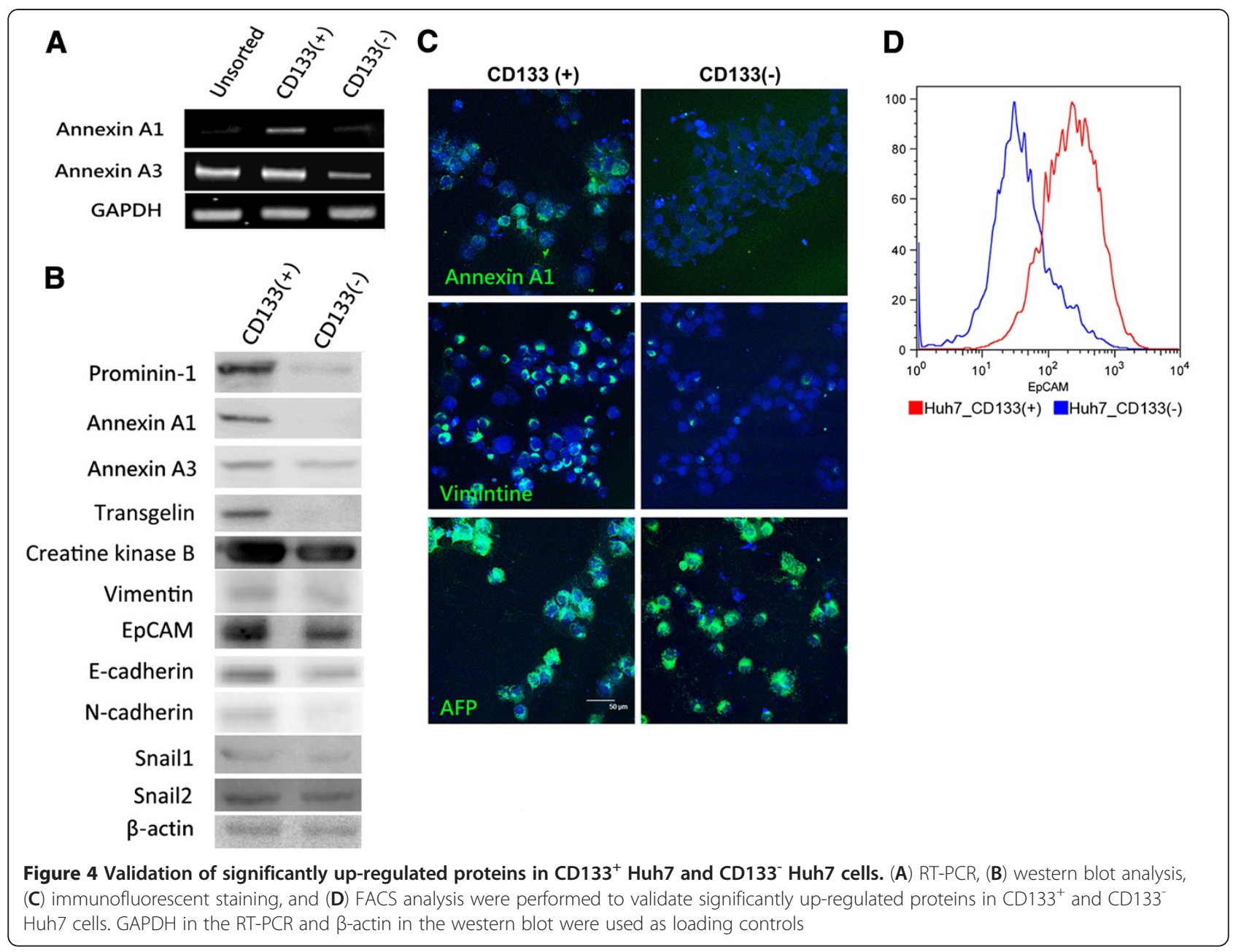

the identified proteins. Twenty-one plasma membrane proteins had higher expression levels in the $\mathrm{CD}_{133^{+}}$ Huh7 cells than in the CD133- Huh7 cells, six of them which has been listed in Table 1 had higher expression levels (>10-fold) in the CD133 ${ }^{+}$Huh7 cells when compared with the hepatocytes. We therefore proposed that these up-regulated plasma membrane proteins can possibly be used as markers for the enriched isolation of liver cancer stem cells.

\section{Signaling molecules identified in the CD133 ${ }^{+}$Huh7 cells} Several signaling pathways have been found in liver cancer stem cells that are involved in self-renewal, survival signaling, and drug resistance $[25,42]$. For example, activation of the $\mathrm{Wnt} / \beta$-catenin pathway has been shown to be associated with a wide variety of cancers [44] and it plays a very important role in regulating the self-renewal of various stem cells and liver progenitors [40]. To investigate the signaling pathway that governing the behavior of liver cancer stem cells, the Kyoto Encyclopedia of Genes and Genomes (KEGG) terms were annotated for the identified proteins. As expected, 21 of the identified proteins were involved in the $\mathrm{Wnt} / \beta$-catenin pathway. In addition to $\mathrm{Wnt} / \beta$-catenin pathway, 41 proteins involved in the MAPK pathway, and 6 proteins involved in the Notch signaling pathway have also been identified (Figure 5). The results implied both MAPK and Notch signaling pathways would also be critical for regulating the tumorigenic behavior of liver CD $133^{+}$CSC subpopulations.

To investigate the protein-protein interactions, the proteins were mapped with the Search Tool for the Retrieval of Interacting Genes/Proteins (STRING) database version 9. STRING is constructed based on both physical and functional interactions. The differentially expressed 151 proteins were analyzed by STRING. To avoid spurious interactions in our large data set, we fetched all interactions that had a confidence score of $\geqq 0.7$ (high confidence). Several interaction groups were immediately apparent and these interaction groups were labeled orange circles (Figure 6). Prominin-1 was correlated with CK-19, nestin, and EpCAM. These proteins were also found to interact with vimentin. Vimentin is a type III intermediate filament (IF) protein that is expressed in liver stem cells. We also found groups of interaction 
Thai et al. Proteome Science 2012, 10:69

Page 8 of 14

http://www.proteomesci.com/content/10/1/69

A

WAT SIGNALING PATHWAY

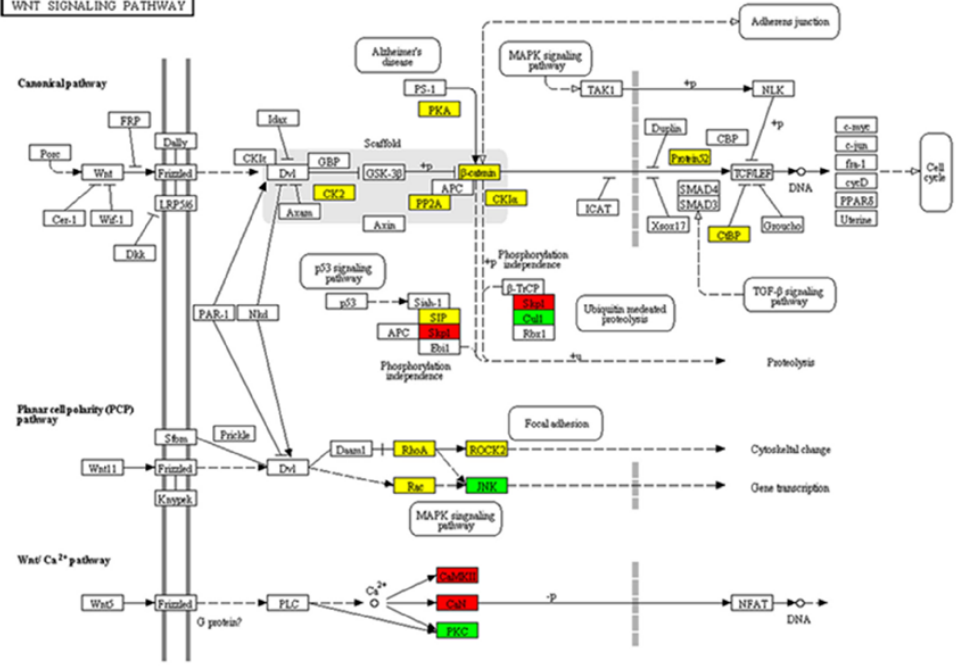

B

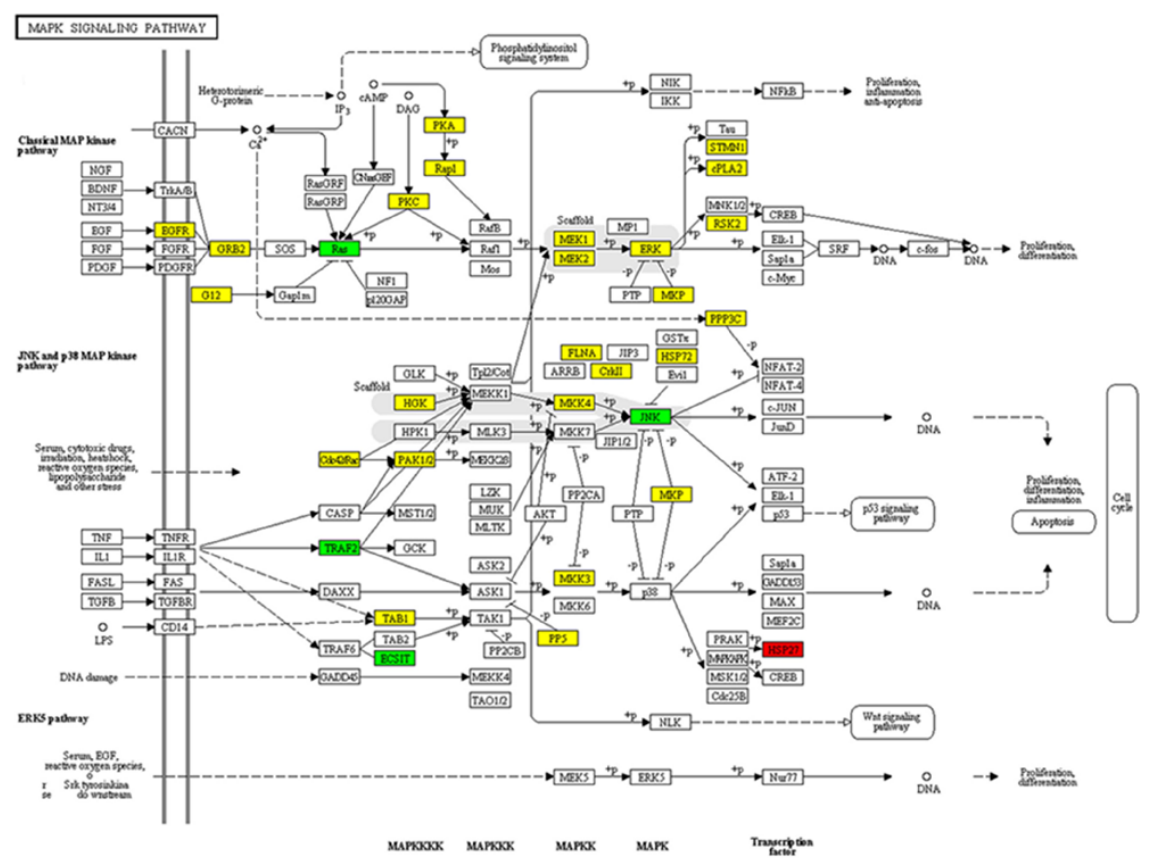

C

NOTCH SIGNALING PATHWAY

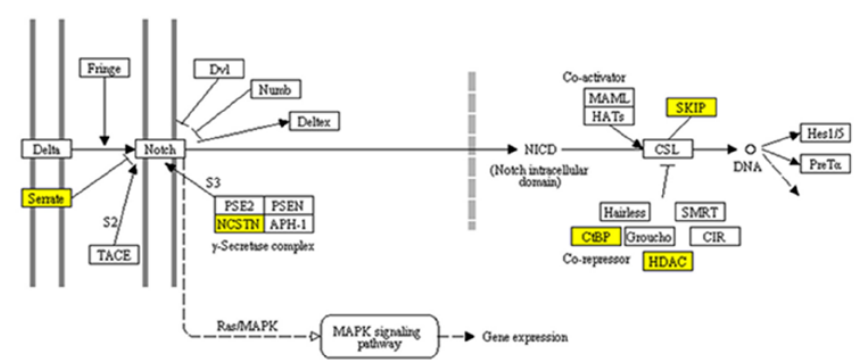

Figure 5 (See legend on next page.) 
(See figure on previous page.)

Figure 5 Pathway analysis. Proteins involved in (A) Wnt/ß-catenin pathway, (B) MAPK pathway, and (C) Notch pathway. The identified proteins were up-regulated (red), down-regulated (green), or showed no significant change (yellow) in CD133+ Huh7 cells

proteins that were involved in the regulation of cytochrome c, glutathione, RNA splicing, and actin polymerization.

\section{Discussion}

In the current study, we not only identified the proteomes of human hepatocytes and CD133 ${ }^{+/-}$Huh7 cells, but we also quantified the abundance of each protein and presented them in parts per million (ppm), which was then used to determine the protein concentration and to classify the individual protein as either a major or minor component. In addition, the protein ratio was used to determine the relative abundance in the $\mathrm{CD} 133^{+/-}$subpopulation. We found that there were 2,590 proteins (77\%) detected in both the $\mathrm{CD}_{133^{+}}$and $\mathrm{CD} 133^{-}$Huh7 cells, but only 1,251 proteins (32\%) were detected in all three cell types, suggesting the $\mathrm{CD}_{133^{+}}$cells and CD133- Huh7 cells have similar characteristics. Some of the calculated protein ratios were found to be different between the IDEA-Q results and the MaxQuant results. Both IDEA-Q and MaxQuant utilized the peptide intensity, retention time and mass to charge, but IDEALQ calculated the top three most abundant peptides and determined the protein ratio by dividing the average

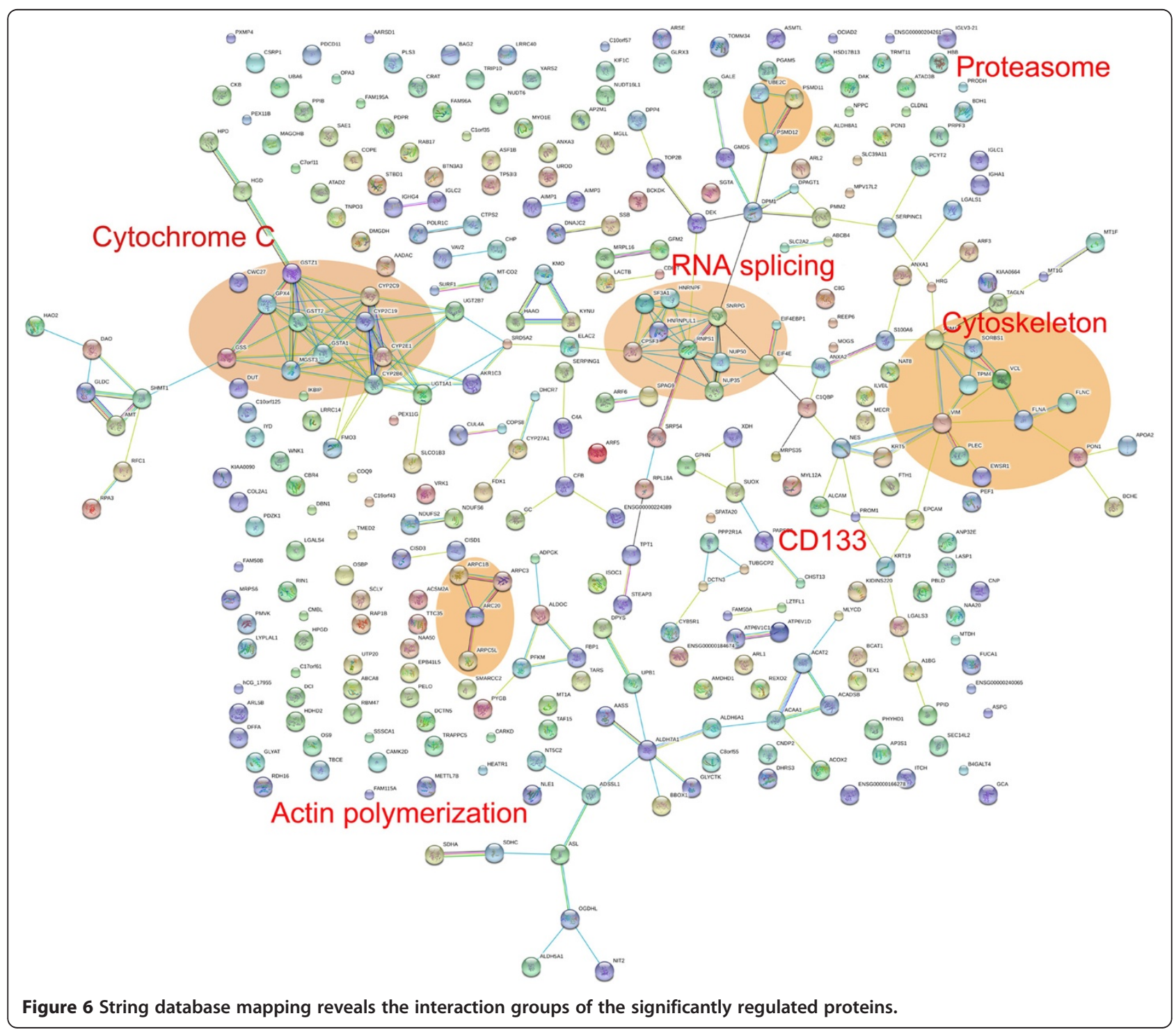


value. In contrast, the MaxQuant platform calculated the protein ratios as the median of all the ratios for the common peptides. The same method was also applied on a second liver cancer cell line, PLC/PRF/5 that expressed the hepatitis B surface antigen (HBsAg). We confirmed that annexin $\mathrm{A} 1$, annexin $\mathrm{A} 3$, creatine kinase $\mathrm{B}$, and transgelin were also up-regulated in $\mathrm{CD} 133^{+} \mathrm{PLC} / \mathrm{PRF} / 5$ cells. The proteomics results of PLC/PRF/5 cells are listed in Additional file 5: Table S5). We presume that this difference could be due to heterogeneity and the different causes of liver cancer. The identified proteins were searched against the GOCC, and we classified 409 IDs as plasma membrane proteins, including hepatic stem cell markers (CD133, CK19, EpCAM, and vimentin). These up-regulated plasma membrane proteins can be used as new surface targets to enrich or investigate liver CSCs. Interestingly, annexin A1 and annexin A3 were both upregulated in the $\mathrm{CD} 133^{+}$Huh7 cells (7.8- and 6.1-fold, respectively). We found that annexin A2 was also slightly up-regulated (1.9-fold). These three proteins all belong to the same subgroup of the annexin family. Annexin A1 binds acidic phospholipids with a high affinity in the presence of calcium ions. It is also an endogenous antiinflammatory protein that has roles in many diverse cellular functions, such as membrane aggregation, inflammation, phagocytosis, proliferation, and apoptosis [45]. In a previous study, primary hepatocytes isolated from normal mice did not express annexin A1, but it was strongly expressed in the liver cells of transgenic mice during the development of hepatocarcinomas. Annexin A1 can be expressed by stimulating epidermal growth factor (EGF) or hepatic growth factor (HGF) [46]. In addition, the up-regulation of annexin A1 in hepatic carcinogenesis has been correlated with the activation of the EGF pathway [47]. In this study, we also observed more protein expression of EGF in the CD133 ${ }^{+}$Huh7 cells. Therefore, annexin A1 could be a potential marker for targeting liver CSCs. Annexin A3 had an approximately six-fold higher expression level in the CD133 ${ }^{+}$Huh7 cells compared with the CD133- Huh7 cells. The role of annexin A3 in cancer is still not fully understood, however, some proteomic studies have shown that annexin A3 is a biomarker in lung adenocarcinomas [48], and an overexpression of annexin A3 was detected in platinumresistant human ovarian cancer cells [49,50]. In the human prostate cancer xenograft model, annexin A3 was up-regulated and drug-resistant both in vivo and in the xenograft [51]. In a previous study, annexin A3 was activated by a hepatocyte growth factor pathway and played an important role in rat liver regeneration [52]. This implies that annexin A3 may be activated by a hepatocyte growth factor in the $\mathrm{CD}_{133^{+}}$Huh7 cells and is involved in liver tumor growth. In this study, EpCAM was highly expressed in the $\mathrm{CD} 133^{+}$Huh7 cells, and it was found to interact with CD133. EpCAM is a biomarker for hepatic stem cells, and it is also expressed in embryonic stem cells [53-56]. In 2009, $\mathrm{EpCAM}^{+} \mathrm{HCC}$ cells were identified as possible liver cancer stem cells, and the expression of EpCAM is regulated by Wnt/ $\beta$-catenin signaling [42]. Currently, several antibody-based therapeutic approaches targeting EpCAM are being developed [57,58]. These reports suggest that EpCAM is not only a biomarker of liver cancer stem cells but also may be a therapeutic target. Metastasis is the main cause of lethality in cancer patients. Cancer stem cells are responsible for both tumor invasion and metastasis $[7,18]$. In the metastasis process, epithelial-mesenchymal transition (EMT) is a transient and reversible switch from an epithelial to a mesenchymal cellular phenotype, to become highly motile and invasive. EMT is regulated by the $\mathrm{Wnt} / \beta$-catenin, TGF $\beta$, and Notch pathways. In this study, we found several proteins that are involved in EMT and that were also up-regulated in the $\mathrm{CD} 133^{+}$Huh7 cells, such as transgelin, vimentin and collagen. Transgelin is a target of TGF $\beta$ signaling that regulates migration and invasion [59]. In addition, it is also co-expressed with several EMTassociated genes, including $\mathrm{N}$-cadherin, vimentin, Snail, and Twist [31]. Vimentin is a mesenchymal marker that was also up-regulated in the $\mathrm{CD}_{133^{+}}$Huh7 cells. Vimentin was also found to be over-expressed in the $\mathrm{HCC}$ tissues, and it is involved in the metastasis of HCC [60]. In addition, vimentin has been found to be expressed in multipotent progenitor cells from human fetal livers [53]. Therefore, we identified higher levels of vimentin in $\mathrm{CD}_{133^{+}}$Huh7 cells, which may imply that the expression of vimentin is an important characteristic of liver CSCs. Translationally controlled tumor protein (TCTP) is a highly conserved, hydrophilic nuclear protein. TCTP is involved in many cellular processes $[61,62]$. For example, TCTP interacts with $B C L-X_{L}$ to protect cells against apoptosis [63,64]. More importantly, a recent report has shown that TCTP is a transcription factor that regulates the pluripotent gene oct4 [65], which is the key factor in regulating the pluripotency of embryonic stem cells. Thus, the higher levels of TCTP identified in the $\mathrm{CD} 133^{+}$Huh7 cells may imply that TCTP plays a role in regulating the stemness properties of liver CSCs.

\section{Conclusions}

With the assistance of the label-free quantitation analysis tool IDEAL-Q and MaxQuant, the current work identified several candidate proteins of liver cancer stem cells, which can possibly be used in the future for targeting liver cancer stem cells. Moreover, the proteome analysis utilized in the present work has provided a comprehensive characterization of $\mathrm{CD}_{133^{+}}$liver cancer stem cells, 
CD133- liver cancer cells, and human hepatocytes. We believe the proteome established in the current work can aid in the understanding of the molecular basis of the tumorigenic liver CSC subpopulations.

\section{Methods}

\section{Cell culture}

The hepatoma cell lines Huh7 and PLC/PRF/5 [66] were maintained in Dulbecco's modified Eagle's medium (Hyclone, South Logan, UT, USA) supplemented with $10 \%$ fetal bovine serum (FBS) (Invitrogen, Carlsbad, CA, USA), 100 units $/ \mathrm{ml}$ of penicillin, and $100 \mu \mathrm{g} / \mathrm{ml}$ of streptomycin (Invitrogen) at $37^{\circ} \mathrm{C}$ in a humidified atmosphere containing $5 \% \mathrm{CO}_{2}$. Human hepatocytes, purchased from PromoCell, were maintained in Hepatocyte Growth Medium (PromoCell, HD, GRE) at $37^{\circ} \mathrm{C}$ in a humidified atmosphere containing $5 \% \mathrm{CO}_{2}$.

\section{Fluorescence-activated cell sorting}

To isolate the $\mathrm{CD}_{133^{+}}$and $\mathrm{CD} 133^{-}$fractions, Huh7 cells were re-suspended in Hank's balanced saline solution (HBSS; Invitrogen) containing 2\% FBS and 10 mM HEPES. The cell density was adjusted to $1 \times 10^{7} / \mathrm{ml}$, and the Huh7 cells were stained with phycoerythrin $(\mathrm{PE})$-conjugated antihuman CD133 antibody (Miltenyi Biotec Inc., Cambridge, MA, USA). After staining, the Huh7 cells were re-suspended in HBSS containing 2\% FBS and $1 \mathrm{mM}$ HEPES and filtered through a $40 \mu \mathrm{m}$ mesh filter, and the $\mathrm{CD} 133^{+}$and $\mathrm{CD} 133^{-}$ Huh7 fractions were sorted by a FACSAria ${ }^{\mathrm{TM}}$ (Becton Dickinson, San Jose, CA, USA).

\section{Sphere forming assay}

Freshly FACS-sorted $\mathrm{CD}_{133^{+}}$and $\mathrm{CD} 133^{-}$Huh7 were plated into ultra-low attachment 6-well plates (Costar, Coining Inc) and cultured in DMEM/F12 medium supplemented with $1 \mathrm{X}$ B27 supplement, $1 \%$ penicillinstreptomycin, $0.4 \%$ bovine serum albumin, $200 \mathrm{ng} / \mathrm{mL}$ epidermal growth factor (EGF), $10 \mathrm{ng} / \mathrm{mL}$ basic fibroblast growth factor (bFGF), $5 \mu \mathrm{g} / \mathrm{mL}$ insulin at $37^{\circ} \mathrm{C}$ in a humidified atmosphere containing $5 \% \mathrm{CO}_{2}$. Spheres were formed after 24 hours. The number of spheres that had diameter over $100 \mu \mathrm{M}$ was count at Day 5 .

\section{RNA extraction and RT-PCR}

To isolate the total RNA, $1 \times 10^{6}$ cells of both the $\mathrm{CD}_{133^{+}}$and $\mathrm{CD} 133^{-}$Huh7 cell fractions were collected in microcentrifuge tubes containing $1 \mathrm{ml}$ TRI Reagent ${ }^{\circledR}$ (Applied Biosystems, Foster City, CA, USA). The RNA was extracted according to the manufacturer's protocol and treated with RQ-1 DNase (Promega, Madison, WI, USA) to remove contaminating genomic DNA. The purity and concentration of the RNA were determined with a NanoDrop ${ }^{\circledR}$ (NanoDrop Technologies, Wilmington, DE, USA). First strand complementary DNA was synthesized using SuperScript III reverse transcriptase (Invitrogen). The PCR reactions were performed with annealing temperatures of $57-58^{\circ} \mathrm{C}$ for either 23 or 35 cycles. The primer sequences used are listed in Additional file 6: Table S6).

\section{Immunofluorescence staining}

The Huh7 cells were either cultured on non-coated glass coverslips or cytospined onto slides at $250 \times g$ for 5 minutes. The cells were fixed with $4 \%$ paraformaldehyde in PBS for 30 minutes, permeabilized with $0.1 \%(\mathrm{v} / \mathrm{v})$ Triton X-100 in PBS for 30 minutes, and incubated in $2 \%$ blocking buffer (Roche, Indianapolis, IN, USA) before sequential incubation with the primary and secondary antibodies. The antibodies were obtained as follows: mouse antihuman $\beta$-catenin was obtained from Becton Dickinson, rabbit anti-human $\alpha$-fetoprotein was obtained from Dako, mouse anti-cytokeratin 19 and mouse anti-vimentin were purchased from Sigma, and the annexin A1 antibody was purchased from Abnova (Taipei City, Taiwan).

\section{Western blotting}

The cell extracts were prepared by lysing unsorted, $\mathrm{CD}_{133^{+}}$, or $\mathrm{CD} 133^{-}$Huh7 cells with RIPA buffer containing $150 \mathrm{mM} \mathrm{NaCl}, 50 \mathrm{mM}$ Tris- $\mathrm{HCl}$ (pH 8), 1\% NP$40, \quad 0.5 \%$ sodium deoxycholate, $0.1 \%$ SDS, protease inhibitors, and phosphatase inhibitors (Sigma). The cell extracts were run on an 8-10\% SDS-PAGE gel and transferred onto a Hybond-P membrane (GE Healthcare, Buckinghamshire, NA, England), which was then probed with the primary antibodies. The antibodies used in the experiments are listed in Additional file 7: Table S7). The signal was detected with an enhanced chemiluminescence kit (GE Healthcare).

\section{TopFlash assay}

TOPFlash reporter (containing seven TCF/LEF binding sites) and FOPFlash reporter (containing six mutant TCF/LEF binding sites which was used as a negative control.) plasmids were originally obtained from Addgene (Dr. Randall Moon). Huh7 cells plated in 6well plates at the density of $3 \times 10^{5}$ cells/well were grown for 24 hours. Either TOPFlash or FOPFlash reporter plasmids $(1 \mu \mathrm{g} /$ well $)$ was transfected together with Renilla control luciferase plasmid (100 ng/well) using Fugene HD (Roche) according to the manufacturer's instructions. 48 hours after transfection, Huh7 cells were harvested and stained with PE conjugated anti-human CD133 antibody. The CD133 ${ }^{+}$and $\mathrm{CD} 133^{-}$Huh7 fractions were sorted by a FACSAria. After sorting, CD133 ${ }^{+}$and CD133- Huh7 cells were lysed, and then firefly and Renilla luciferase activities were measured using the DualLuciferase Reporter Assay System (Promega). 


\section{Drug resistance assay}

Huh7 cells were seeded at the density of 7,500 cells/well in 96-well plates and were treated with a serial dilution of 5-FU or Sorafenib for 48 hours. The cytotoxicity of the drug was determined using a 3-(4,5-dimethylthiazol2-yl)-2,5-diphenyltertrazolium bromide (MTT) colorimetric assay (Sigma).

\section{In-gel digestion}

The cell lysates were separated on a $12 \%$ polyacrylamide gel $(10 \times 10 \mathrm{~cm}, 0.75 \mathrm{~mm}$ thick), and the protein patterns were observed by Coomassie blue staining. Each lane was separated into 16 sections, and each section was cut into $0.75 \mathrm{~mm}^{3}$ cubes. The gel pieces were destained with a $25 \mathrm{mM} \mathrm{NH} \mathrm{NH}_{4} \mathrm{HCO}_{3} / 50 \%$ acetonitrile (ACN) solution. After reduction and alkylation reactions using $10 \mathrm{mM}$ DTT and $55 \mathrm{mM}$ iodoacetamide, respectively, the proteins were digested overnight with modified trypsin (Promega, Madison, WI, USA) at $37^{\circ} \mathrm{C}$. The tryptic peptides were extracted with $1 \%$ trifluoroacetic acid (TFA)/60\% ACN. After lyophilization, the extracted peptides were re-dissolved in a $0.1 \%$ TFA solution.

\section{LC-MS/MS analysis}

The mass analysis experiments were performed using a 7Tesla LTQ-FT-ICR (Linear quadrupole ion trap Fourier transform ion cyclotron resonance) mass spectrometer (Thermo Fisher Scientific, Waltham, MA, USA) equipped with a nanoelectrospray ion source (New Objective Inc., Woburn, MA, USA), an Agilent 1100 Series binary highperformance liquid chromatography pump (Agilent Technologies, Palo Alto, CA, USA), and a FAMOS autosampler (LC Packings, San Francisco, CA, USA). The peptide mixtures were injected $(5 \mu \mathrm{l})$ at a flow rate of $10 \mu \mathrm{l} / \mathrm{min}$ onto a self-packed pre-column $(150 \mu \mathrm{m}$ I.D. $\times 15 \mathrm{~mm}, 5 \mu \mathrm{m}$, $100 \AA$ A). The chromatographic separation was performed on a self-packed reversed phase C18 nano-column $(75 \mu \mathrm{m}$ I.D. $\times 300 \mathrm{~mm}, 5 \mu \mathrm{m}, 100 \AA$ ) at $300 \mathrm{nl} / \mathrm{min}$ with a $60 \mathrm{~min}$ gradient of 0 to $32 \%$ acetonitrile in $0.1 \%$ formic acid. The electrospray voltage was maintained at $2.5 \mathrm{kV}$, and the capillary temperature was set at $200^{\circ} \mathrm{C}$. The full-scan MS spectra $(m / z$ 300-1800) were acquired with the FT-ICR with a mass resolution of 100,000 at $\mathrm{m} / z$ 400. After the completion of the full-scan survey, the 10 most abundant ions detected in the full-MS scan were selected for peptide sequence determinations using MS/MS experiments. Each sample was analyzed in duplicate.

\section{Protein identification}

The peak-list files were obtained from the MS/MS data using Extract_msn 4.0 software (Thermo), which included the mass values and the intensity and charge of the precursor ions (parent ions with +2 or +3 charges in this study). For protein identification, the MS/MS data were submitted to the International Protein Index (IPI) human protein database (release $3.43,72,340$ sequences) using the MASCOT 2.2.2 search engine (Matrix Science, Boston, MA, USA) with the following settings: trypsin cleavage; a peptide mass matching error tolerance of $5 \mathrm{ppm}$; a fragment mass tolerance of $0.5 \mathrm{Da}$; fixed modification of carbamidomethylation of cysteine; variable modifications of deamidation of asparagine and glutamine, oxidation of methionine; a maximum of two missed cleavages; an ion score cutoff of $33(p<0.003)$; and a false discovery rate of $<1.1 \%$. The false discovery rate was calculated by decoy database searching. The results were imported into Microsoft Excel for further analysis.

\section{Quantitative data analysis}

The IDEAL-Q method, which was developed previously [34], was utilized to process the LC-MS/MS data, and the Mascot search engine was used to extract the quantitative information. In brief, the raw data files were first converted into the mzXML data format by the ReAdW program (http://tools.proteomecenter.org/wiki/index.php? title=Software:ReAdW). The resulting mzXML files and the Mascot search results for the peptide and protein identification were used as the input for the quantitative tool. To process a peptide of an LC-MS run, we extracted the LC-MS data within the range of \pm 1.5 minutes of its elution time and $\pm 3.5 \mathrm{Da}$ of the precursor $\mathrm{m} / z$ value for quantitative analysis. We used the extracted ion chromatogram (XIC) to determine the peptide abundance in an LC-MS run. After determining the peptide abundance for each LC-MS run, we calculated the fraction's peptide abundance by averaging the peptide abundances of the valid peptides in all of the LC-MS runs for the fraction. To determine the peptide abundance in a sample, we summed all of the peptide fraction abundances in the sample, and the peptide ratio between two samples was also calculated. To calculate the protein ratio, we selected the nondegenerate peptides and performed the Dixon's test to eliminate the outliers for each protein. We then averaged the abundances of the top three most abundant peptides, and the protein ratio was determined by dividing the average value for each of the different cell types. The upregulated or down-regulated proteins were defined as having a protein ratio with a significant change $(p<0.01)$. Label-free quantitation was also performed in MaxQuant $[35,36]$ version 1.2.0.18. The significance $B$ and $p$-values were calculated by Perseus software.

\section{Additional files}

Additional file 1: Table S1. The information of identified proteins in hepatocytes.

Additional file 2: Table S2. The information of identified proteins in CD133 ${ }^{+}$Huh7 cells. 
Additional file 3: Table S3. The information of identified proteins in CD133- Huh7 cells.

Additional file 4: Table S4. Significant proteins in $\mathrm{CD} 133^{+}$Huh7 cells. Additional file 5: Table S5. The information of identified proteins in $\mathrm{PLC} / \mathrm{PRF} / 5$ cells.

Additional file 6: Table S6. The primer sequences for RT-PCR. Additional file 7: Table S7. The antibodies information for Western blot.

\section{Abbreviations}

ACN: Acetonitrile; CSCs: Cancer stem cells; HCC: Hepatocellular carcinoma; IDEAL-Q: ID-based Elution time alignment by linear regression quantitation; PE: Phycoerythrin; TICs: Tumor-initiating cells; XIC: Extracted ion chromatogram.

\section{Competing interests}

The authors declare that they have no competing interests.

\section{Authors' contributions}

STT carried out the experiment, analyzed data and wrote the manuscript. CCT and WLH created the software to analyzed data. WYM, HYH collected the cells and participated in the experiments. WCC provided expertise in experimental design and interpretation of analytical results. CLL help to develop Topflash assay. CNS and CHC conceived of the study, interpretation of analytical results and drafted the manuscript. All authors read and approved the final manuscript.

\section{Acknowledgements}

This work was supported by the Genomics Research Center, Academia Sinica, the National Science Council of Taiwan (NSC 99-2113-M-001-002MY3), and the National Health Research Institute in Taiwan (NHRI-EX1019803El). The authors would like to acknowledge Miss Chiao-Yun Chien for assistance with immunofluorescent staining and Ms. K. J. Cherry Lin for help with manuscript preparation. Dr. P. R. Sudhir and Ms. Y. C. Sara Hu are acknowledged for their critical reading of the manuscript. This work was supported by the Genomics Research Center, Academia Sinica, and the National Health Research Institute.

\section{Author details}

${ }^{1}$ Institute of Biochemistry \& Molecular Biology, National Yang-Ming University, Taipei, Taiwan. ${ }^{2}$ Genomics Research Center, Academia Sinica, Taipei, Taiwan. ${ }^{3}$ Institute of Information Science, Academia Sinica, Taipei, Taiwan. ${ }^{4}$ Institute of Cellular and Organismic Biology, Academia Sinica, Taipei, Taiwan. ${ }^{5}$ Department of Chemistry, National Taiwan University, Taipei, Taiwan. ${ }^{6}$ Institute of Atomic \& Molecular Sciences, Academia Sinica, Taipei, Taiwan.

\section{Received: 25 June 2012 Accepted: 2 November 2012}

Published: 21 November 2012

\section{References}

1. Dalerba P, Cho RW, Clarke MF: Cancer stem cells: models and concepts. Annu Rev Med 2007, 58:267-284.

2. Visvader JE, Lindeman GJ: Cancer stem cells in solid tumours: accumulating evidence and unresolved questions. Nat Rev Cancer 2008, 8:755-768.

3. Vermeulen L, Sprick MR, Kemper K, Stassi G, Medema JP: Cancer stem cells-old concepts, new insights. Cell Death Differ 2008, 15:947-958.

4. Bonnet D, Dick JE: Human acute myeloid leukemia is organized as a hierarchy that originates from a primitive hematopoietic cell. Nat Med 1997, 3:730-737.

5. Lapidot T, Sirard C, Vormoor J, Murdoch B, Hoang T, Caceres-Cortes J, Minden M, Paterson B, Caligiuri MA, Dick JE: A cell initiating human acute myeloid leukaemia after transplantation into SCID mice. Nature 1994, 367:645-648.

6. Fang D, Nquyen TK, Leishear K, Finko R, Kulp AN, Hotz S, Van Belle PA, Xu X, Elder DE, Herlyn M: A tumorigenic subpopulation with stem cell properties in melanomas. Cancer Res 2005, 65:9328-9337.

7. Al-Hajj M, Wicha MS, Ito-Hernandez A, Morrison SJ, Clarke MF: Prospective identification of tumorigenic breast cancer cells. Proc Natl Acad Sci USA 2003, 100:3983-3988.
8. Singh SK, Hawkins C, Clarke ID, Squire JA, Bayani J, Hide T, Henkelman RM, Cusimano MD, Dirks PB: Identification of human brain tumour initiating cells. Nature 2004, 432:396-401.

9. Singh SK, Clarke ID, Terasaki M, Bonn VE, Hawkins C, Squire J, Dirks PB: Identification of a cancer stem cell in human brain tumors. Cancer Res 2003, 63:5821-5828.

10. Collins AT, Berry PA, Hyde C, Stower MJ, Maitland NJ: Prospective identification of tumorigenic prostate cancer stem cells. Cancer Res 2005, 65:10946-10951.

11. Prince ME, Sivanandan R, Kaczorowski A, Wolf GT, Kaplan MJ, Dalerba P, Weissman IL, Clarke MF, Ailles LE: Identification of a subpopulation of cells with cancer stem cell properties in head and neck squamous cell carcinoma. Proc Natl Acad Sci USA 2007, 104:973-978.

12. Eramo A, Lotti F, Sette G, Pilozzi E, Biffoni M, Di VA, Conticello C, Ruco L, Peschle C, De MR: Identification and expansion of the tumorigenic lung cancer stem cell population. Cell Death Differ 2008, 15:504-514.

13. Ricci-Vitiani L, Lombardi DG, Pilozzi E, Biffoni M, Todaro M, Peschle C, De MR: Identification and expansion of human colon-cancer-initiating cells. Nature 2007, 445:111-115.

14. O'Brien CA, Pollett A, Gallinger S, Dick JE: A human colon cancer cell capable of initiating tumour growth in immunodeficient mice. Nature 2007, 445:106-110.

15. Li C, Heidt DG, Dalerba P, Burant CF, Zhang L, Adsay V, Wicha M, Clarke MF, Simeone DM: Identification of pancreatic cancer stem cells. Cancer Res 2007, 67:1030-1037.

16. Zhang S, Balch C, Chan MW, Lai HC, Matei D, Schilder JM, Yan PS, Huang $\mathrm{TH}$, Nephew KP: Identification and characterization of ovarian cancer-initiating cells from primary human tumors. Cancer Res 2008, 68:4311-4320.

17. Ma S, Chan KW, Hu L, Lee TK, Wo JY, Ng IO, Zheng BJ, Guan XY: Identification and characterization of tumorigenic liver cancer stem/progenitor cells. Gastroenterology 2007, 132:2542-2556.

18. Yang ZF, Ho DW, Ng MN, Lau CK, Yu WC, Ngai P, Chu PW, Lam CT, Poon RT Fan ST: Significance of CD90+ cancer stem cells in human liver cancer. Cancer Cell 2008, 13:153-166.

19. Mizrak D, Brittan M, Alison MR: CD133: molecule of the moment. J Pathol 2008, 214:3-9.

20. Yin AH, Miraglia S, Zanjani ED, Meida-Porada G, Ogawa M, Leary AG, Olweus J, Kearney J, Buck DW: AC133, a novel marker for human hematopoietic stem and progenitor cells. Blood 1997, 90:5002-5012.

21. Schmelzer E, Zhang L, Bruce A, Wauthier E, Ludlow J, Yao HL, Moss N, Melhem A, McClelland R, Turner W, et al: Human hepatic stem cells from fetal and postnatal donors. J Exp Med 2007, 204:1973-1987.

22. Hermann PC, Huber SL, Herrler T, Aicher A, Ellwart JW, Guba M, Bruns CJ, Heeschen C: Distinct populations of cancer stem cells determine tumor growth and metastatic activity in human pancreatic cancer. Cell Stem Cell 2007, 1:313-323.

23. Yin S, Li J, Hu C, Chen X, Yao M, Yan M, Jiang G, Ge C, Xie H, Wan D, et al: CD133 positive hepatocellular carcinoma cells possess high capacity for tumorigenicity. Int J Cancer 2007, 120:1444-1450.

24. Suetsugu A, Nagaki M, Aoki H, Motohashi T, Kunisada T, Moriwaki H: Characterization of CD133+ hepatocellular carcinoma cells as cancer stem/progenitor cells. Biochem Biophys Res Commun 2006, 351:820-824

25. Ma S, Lee TK, Zheng BJ, Chan KW, Guan XY: CD133+ HCC cancer stem cells confer chemoresistance by preferential expression of the Akt/PKB survival pathway. Oncogene 2008, 27:1749-1758.

26. Yeh CT, Kuo CJ, Lai MW, Chen TC, Lin CY, Yeh TS, Lee WC: CD133-positive hepatocellular carcinoma in an area endemic for hepatitis $B$ virus infection. BMC Cancer 2009, 9:324.

27. Song W, Li H, Tao K, Li R, Song Z, Zhao Q, Zhang F, Dou K: Expression and clinical significance of the stem cell marker CD133 in hepatocellular carcinoma. Int J Clin Pract 2008, 62:1212-1218.

28. Ong SE, Mann M: Mass spectrometry-based proteomics turns quantitative. Nat Chem Biol 2005, 1:252-262.

29. Cox J, Mann M: Is proteomics the new genomics? Cell 2007, 130:395-398.

30. Graumann J, Hubner NC, Kim JB, Ko K, Moser M, Kumar C, Cox J, Scholer H, Mann M: Stable isotope labeling by amino acids in cell culture (SILAC) and proteome quantitation of mouse embryonic stem cells to a depth of 5,111 proteins. Mol Cell Proteomics 2008, 7:672-683.

31. Lee EK, Han GY, Park HW, Song YJ, Kim CW: Transgelin promotes migration and invasion of cancer stem cells. J Proteome Res 2010, 9:5108-5117. 
32. Ma S, Chan KW, Lee TK, Tang KH, Wo JY, Zheng BJ, Guan XY: Aldehyde dehydrogenase discriminates the CD133 liver cancer stem cell populations. Mol Cancer Res 2008, 6:1146-1153.

33. Van Houdt WJ, Emmink BL, Pham TV, Piersma SR, Verheem A, Vries RG, Fratantoni SA, Pronk A, Clevers H, Borel R R, et al: Comparative proteomics of colon cancer stem cells and differentiated tumor cells identifies BIRC6 as a potential therapeutic target. Mol Cell Proteomics 2011, 10:M111.

34. Tsou CC, Tsai CF, Tsui YH, Sudhir PR, Wang YT, Chen YJ, Chen JY, Sung TY, Hsu WL: IDEAL-Q, an automated tool for label-free quantitation analysis using an efficient peptide alignment approach and spectral data validation. Mol Cell Proteomics 2010, 9:131-144.

35. Cox J, Mann M: MaxQuant enables high peptide identification rates, individualized p.p.b.-range mass accuracies and proteome-wide protein quantification. Nat Biotechnol 2008, 26:1367-1372.

36. Waanders LF, Chwalek K, Monetti M, Kumar C, Lammert E, Mann M: Quantitative proteomic analysis of single pancreatic islets. Proc Natl Acad Sci USA 2009, 106:18902-18907.

37. Tsuchiya A, Heike T, Fujino H, Shiota M, Umeda K, Yoshimoto M, Matsuda Y, Ichida T, Aoyagi Y, Nakahata T: Long-term extensive expansion of mouse hepatic stem/progenitor cells in a novel serum-free culture system. Gastroenterology 2005, 128:2089-2104.

38. Uchida Y, Tanaka S, Aihara A, Adikrisna R, Yoshitake K, Matsumura S, Mitsunori Y, Murakata A, Noguchi N, Irie T, et al: Analogy between sphere forming ability and stemness of human hepatoma cells. Oncol Rep 2010, 24:1147-1151

39. Cao L, Zhou Y, Zhai B, Liao J, Xu W, Zhang R, Li J, Zhang Y, Chen L, Qian H, et al: Sphere-forming cell subpopulations with cancer stem cell properties in human hepatoma cell lines. BMC Gastroenterol 2011, 11:71.

40. Yang W, Yan HX, Chen L, Liu Q, He YQ, Yu LX, Zhang SH, Huang DD, Tang $L$, Kong $X N$, et al: Wnt/beta-catenin signaling contributes to activation of normal and tumorigenic liver progenitor cells. Cancer Res 2008, 68:4287-4295.

41. Apte U, Thompson MD, Cui S, Liu B, Cieply B, Monga SP: Wnt/beta-catenin signaling mediates oval cell response in rodents. Hepatology 2008, 47:288-295

42. Yamashita $T$, Ji J, Budhu A, Forgues $M$, Yang W, Wang HY, Jia H, Ye Q, Qin

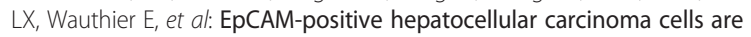
tumor-initiating cells with stem/progenitor cell features. Gastroenterology 2009, 136:1012-1024.

43. Dang $H$, Ding W, Emerson D, Rountree CB: Snail1 induces epithelial-to-mesenchymal transition and tumor initiating stem cell characteristics. BMC Cancer 2011, 11:396.

44. Taipale J, Beachy PA: The Hedgehog and Wnt signalling pathways in cancer. Nature 2001, 411:349-354.

45. Lim LH, Pervaiz S: Annexin 1: the new face of an old molecule. FASEB J 2007, 21:968-975.

46. Della GB, Braut-Boucher F, Bomsel M, Chatelet F, Guguen-Guillouzo C, Font J, Weinman J, Weinman S: Annexin expressions are temporally and spatially regulated during rat hepatocyte differentiation. Dev Dyn 2001, 222:206-217.

47. De Coupade C, Gillet R, Bennoun M, Briand P, Russo-Marie F, Solito E: Annexin 1 expression and phosphorylation are upregulated during liver regeneration and transformation in antithrombin III SV40 T large antigen transgenic mice. Hepatology 2000, 31:371-380.

48. Liu YF, Xiao ZQ, Li MX, Li MY, Zhang PF, Li C, Li F, Chen YH, Yi H, Yao HX, et al: Quantitative proteome analysis reveals annexin $\mathrm{A} 3$ as a novel biomarker in lung adenocarcinoma. J Pathol 2009, 217:54-64.

49. Yan X, Yin J, Yao H, Mao N, Yang Y, Pan L: Increased expression of annexin $\mathrm{A} 3$ is a mechanism of platinum resistance in ovarian cancer. Cancer Res 2010, 70:1616-1624.

50. Yan XD, Pan LY, Yuan Y, Lang JH, Mao N: Identification of platinum-resistance associated proteins through proteomic analysis of human ovarian cancer cells and their platinum-resistant sublines. J Proteome Res 2007, 6:772-780.

51. Thoenes L, Hoehn M, Kashirin R, Ogris M, Arnold GJ, Wagner E, Guenther M: In vivo chemoresistance of prostate cancer in metronomic cyclophosphamide therapy. J Proteomics 2010, 73:1342-1354.

52. Harashima M, Harada K, Ito $Y$, Hyuga M, Seki T, Ariga T, Yamaguchi T, Niimi $\mathrm{S}$ : Annexin $\mathrm{A} 3$ expression increases in hepatocytes and is regulated by hepatocyte growth factor in rat liver regeneration. J Biochem 2008, 143:537-545.
53. Dan YY, Riehle KJ, Lazaro C, Teoh N, Haque J, Campbell JS, Fausto N: Isolation of multipotent progenitor cells from human fetal liver capable of differentiating into liver and mesenchymal lineages. Proc Natl Acad SCi USA 2006, 103:9912-9917.

54. Schmelzer E, Wauthier E, Reid LM: The phenotypes of pluripotent human hepatic progenitors. Stem Cells 2006, 24:1852-1858.

55. Lu TY, Lu RM, Liao MY, Yu J, Chung CH, Kao CF, Wu HC: Epithelial cell adhesion molecule regulation is associated with the maintenance of the undifferentiated phenotype of human embryonic stem cells. J Biol Chem 2010, 285:8719-8732

56. Ng VY, Ang SN, Chan JX, Choo AB: Characterization of epithelial cell adhesion molecule as a surface marker on undifferentiated human embryonic stem cells. Stem Cells 2010, 28:29-35.

57. Kurtz JE, Dufour P: Adecatumumab: an anti-EpCAM monoclonal antibody, from the bench to the bedside. Expert Opin Biol Ther 2010, 10:951-958.

58. Gires O, Bauerle PA: EpCAM as a target in cancer therapy. J Clin Oncol 2010, 28:e239-e240.

59. Yu H, Konigshoff M, Jayachandran A, Handley D, Seeger W, Kaminski N, Eickelberg O: Transgelin is a direct target of TGF-beta/Smad3-dependent epithelial cell migration in lung fibrosis. FASEB J 2008, 22:1778-1789.

60. Hu L, Lau SH, Tzang CH, Wen JM, Wang W, Xie D, Huang M, Wang Y, Wu MC, Huang JF, et al: Association of Vimentin overexpression and hepatocellular carcinoma metastasis. Oncogene 2004, 23:298-302.

61. Bommer UA, Thiele BJ: The translationally controlled tumour protein (TCTP). Int J Biochem Cell Biol 2004, 36:379-385.

62. Telerman A, Amson R: The molecular programme of tumour reversion: the steps beyond malignant transformation. Nat Rev Cancer 2009, 9:206-216.

63. Liu H, Peng HW, Cheng YS, Yuan HS, Yang-Yen HF: Stabilization and enhancement of the antiapoptotic activity of mcl-1 by TCTP. Mol Cell Biol 2005, 25:3117-3126.

64. Yang $Y$, Yang F, Xiong Z, Yan $Y$, Wang $X$, Nishino M, Mirkovic D, Nguyen J, Wang $\mathrm{H}$, Yang $\mathrm{XF}$ : An N-terminal region of translationally controlled tumor protein is required for its antiapoptotic activity. Oncogene 2005, 24:4778-4788

65. Koziol MJ, Garrett N, Gurdon JB: Tpt1 activates transcription of oct4 and nanog in transplanted somatic nuclei. Curr Biol 2007, 17:801-807.

66. Nakabayashi H, Taketa K, Miyano K, Yamane T, Sato J: Growth of human hepatoma cells lines with differentiated functions in chemically defined medium. Cancer Res 1982, 42:3858-3863.

doi:10.1186/1477-5956-10-69

Cite this article as: Tsai et al:: Label-free quantitative proteomics of CD133-positive liver cancer stem cells. Proteome Science 2012 10:69.

\section{Submit your next manuscript to BioMed Central and take full advantage of:}

- Convenient online submission

- Thorough peer review

- No space constraints or color figure charges

- Immediate publication on acceptance

- Inclusion in PubMed, CAS, Scopus and Google Scholar

- Research which is freely available for redistribution 